\title{
AS TECITURAS DO PROCESSO DE REORGANIZAÇÃO SOCIAL KRENYÊ
}

\section{THE WEAVING OF PROCESS OF SOCIAL REORGANISATION KRENYÊ}

\author{
Mônica Ribeiro Moraes de Almeida* \\ João Damasceno Gonçalves Figueiredo Jr**
}

\section{Introdução}

No início do século XXI, um conjunto de "atores" que vive no município de Barra do Corda/MA, começou a reverter sua condição étnica. Estes atores, antes denominados Timbira, passaram a afirmar o pertencimento a uma etnia considerada extinta, os Krenyê de Bacabal e, a partir disso, a exigir o reconhecimento da identidade étnica e a demarcação de um território. Este artigo trata de alguns elementos constitutivos deste processo de reorganização social Krenyê.
Os Krenyê foram classificados ${ }^{1}$ (NIMEUNDAJÚ, 1946) como parte de um conjunto maior de povos falantes da língua Timbira, dentro do tronco linguístico Macro Jê (RODRIGUES, 1986).

Os Timbira, que habitavam as áreas de cerrado do Maranhão, tiveram seus territórios invadidos no início do século XIX, por sertanejos nordestinos criadores de gado (RIBEIR0, 1996) que encontraram nos territórios nativos áreas apropriadas para a criação de gado. Segundo Nimuendajú (1946), viviam em uma faixa de terra entrecortada pelos rios Tocantins, Gurupi, Grajaú, Mea-

\footnotetext{
* Doutora em Ciências Sociais pela Universidade Federal do Maranhão (UFMA). Professora da Universidade Federal do Maranhão - UFMA (Barra do Corda/MA/BR). monicarma@gmail.com.

${ }^{*}$ Mestre em Cartografia Social e Política da Amazônia pela Universidade Estadual do Maranhão. Antropólogo do Serviço de Etnologia do Centro de Pesquisa de História Natural e Arqueologia do Maranhão CPH/NAMA (São Luís/MA/BR). damasceno.etnos@gmail.com.

1. Utilizaremos uma grafia diferente daquela grafada por Nimuendajú. Este povo foi grafado por Nimuendajú como Krēyé. Iremos respeitar neste texto a forma como os atores se autodenominam, Krenyê.
} 
rim e Parnaíba - uma área entre o norte de Goiás e o sul do Maranhão.

As intensas e paulatinas invasões de seus territórios causaram constantes migrações dos povos que habitavam essa região, na tentativa de fugir dos invasores. Entretando, sem ter muito onde se esconder, já que as povoações cresciam rapidamente espalhando-se pelo território, tornaram-se um "transtorno" para os invasores. Os Timbiras trouxeram, então, insegurança para aqueles que se instalaram e passaram a viver da lavoura do algodão, milho, arroz, mandioca e mamona (DA COSTA, 2006).

Os Krenyê viviam em uma área denominada "Pedra do Salgado", localizada na região do Médio Mearim, onde hoje se localizam os municípios de Bacabal e Vitorino Freire. Viveram nessa região até aproximadamente as décadas de 1940 e 1950, quando foram atingidos por uma grande epidemia de sarampo em que muitos índios morreram e outros fugiram, indo se abrigar na terra de outros povos indígenas.

Nesse mesmo período, os Krenyê e os Pobzé, povo que vivia próximo a eles, começaram a se apresentar pacificamente aos moradores da região de Bacabal e Médio Mearim (MACHADO, 1856, apud NIMUENDAJÚ, 1946). Foram, então, criadas duas colônias de índios², através do regulamen- to de 11 de abril de 1854: uma à margem do rio Pindaré e outra no Alto Mearim esta última denominada Colônia Leopoldina e a primeira, Colônia Januária. Essas colônias deveriam observar todas as disposições da Lei provincial $n^{\circ} 85$ de 2 de julho de $1839^{3}$.

A Colônia Leopoldina, objetivava o aldeamento dos Krenyê, dos Kukóekamekra e dos Pobzé (NIMUENDAJÚ, 1946; GOMES, 2002). Desse modo, os diretores das colônias garantiriam o controle desses povos, para que não constituíssem empecilho aos projetos desenvolvimentistas que começavam a se implantar no país naquele período, como bem afirmou Coelho (1991).

A expulsão completa de seu território se deu na década de 1960 , quando já estavam em pouco número e não tinham mais como lutar para permanecer. Com o processo de dispersão, passaram a viver de forma fragmentada junto a outros povos indígenas e a ser conhecidos genericamente como Timbira.

0 processo vivenciado pelos Krenyê assemelha-se ao de muitos povos indígenas no Brasil, principalmente no Nordeste, que foram classificados em inúmeros trabalhos pelo termo etnogênese. Essa dinâmica, embora possua uma concentração no Nordeste, pode ser observada de norte a sul do país (ARRUTI, 2006).

2. Nessa época o governo Imperial ordenava a criação de colônias ou missões com o intuito de acabar com a ameaça que os índios representavam aqueles que pretendiam colonizar a região, bem como de transformar os índios em mão de obra.

3. Esta lei determina que as missões devem ser "assentadas em terras próprias para lavrar, ou contíguas a estas, mas nas proximidades dos rios e campos de criar” (MARANHÃO, 1839). Somente os indígenas instalados nessas terras estariam autorizados a nelas lavrar. Seriam administradas por um diretor, que deveria promover os meios de subsistência entre os indígenas, ensinando-lhes a lavrar a terra a maneira do país e a criar animais domésticos para o consumo das missões. Também deveriam contar com a presença de um missionário, cabendo a este ensinar o amor ao trabalho e à vida social. 0 uso da força coercitiva era permitido. 
A utilização do termo etnogênese tem sido feita usualmente para "designar diferentes processos sociais protagonizados pelos grupos étnicos" (BARTOLOMÉ, 2006, p. 39). É importante destacar que etnogênese não se trata de um conceito ou noção, como bem alertou Pacheco de Oliveira (1998, p.62), e utilizá-la desse modo pode acabar "substantivando um processo que é histórico". 0 mesmo cuidado deve-se ter com a utilização do termo "emergência", pois passa a ideia de um movimento de "natureza física e mecânica quanto ao estudo da dinâmica dos corpos" o que tende a gerar um entendimento distorcido quando aplicada ao domínio dos fenômenos humanos (OLIVEIRA, 1998, p. 62).

Assim, etnogênese, e por que não dizer também emergência, refere-se a processos históricos e dinâmicas sociais que revelam maleabilidade e "capacidade adaptativa", muitas vezes não levadas em consideração em algumas análises antropológicas que tendiam a tratar tais fenômenos com estáticos (BARTOLOMÉ, 2006, p. 40). Isso implica dizer que o fenômeno conhecido como etnogênese refere-se a um processo de emergência política de afırmação de identidades étnicas, que faz surgir um novo tipo de "sujeito político" (ARRUTI, 1997). Ainda segundo Arruti, esses novos "sujeitos políticos” são levados à maximização de alteridades para subverterem as indistinções sociais e culturais em que se encontravam e, dessa forma, obterem reconhecimento de suas identidades étnicas.

Assim, neste artigo, buscamos analisar o processo de reorganização social de um povo que se sentindo "sujeitos" capazes de receberem direitos (HONNETH, 2003) passam a demandar do Estado reconhecimento identitário e territorial. Para tanto, buscaremos brevemente contextualizar histórica e socialmente o movimento político Krenyê. Dessa forma, concordamos com Honneth quando afirma que,

\begin{abstract}
[...] saber empiricamente se o potencial cognitivo, inerente aos sentimentos da vergonha social e da vexação, se torna uma convicção política e moral depende, sobretudo, de como está constituído o entorno político e cultural dos sujeitos atingidos - somente quando o meio de articulação de um movimento social está disponível é que a experiência de desrespeito pode tornar-se uma fonte de motivação para ações de resistência política. (HONNETH, 2009, p. 224)
\end{abstract}

A luta por reconhecimento se dá por um processo de interação, e como afirmou Cardoso de Oliveira (2006, p. 35) "será nas sociedades multiculturais que a questão da identidade étnica e de seu reconhecimento vai se tornar ainda mais crítica, tendendo a gerar crises individuais ou coletivas".

No processo de luta por reconhecimento, o contato interétnico é essencial para a constituição dos “grupos étnicos", já que ele direciona a organização interna e a identidade desse "grupo" (OLIVEIRA, 1988). Dessa forma, o "grupo" se organiza não só ligado a elementos internos, não é algo natural, mas passa pela percepção da diferença reconhecida pelos grupos na situação de contato.

Isso nos leva a outros autores que contribuíram para a análise que fazemos sobre o processo vivenciado pelos Krenyê, são eles: Weber (2000) e Barth (1998). Weber nos convida a pensar a formação dos grupos étnicos a partir das relações sociais que estes estabelecem, ou seja, o que define uma “comunidade étnica" não é a soma das diferenças, mas como os sujeitos, em interação, demarcam, selecionam e constroem as diferenças entre si. 
0 que importa para Weber é apreender a dimensão política e a ação social daquilo que conceituou como "grupos étnicos".

Barth defıniu "grupos étnicos" como tipo organizacional. Da mesma forma que Weber, Barth também considera que "as características que são levadas em consideração não são a soma das diferenças 'objetivas', mas somente aquelas que os próprios atores consideram significantes" (1998, p.194). Dessa forma, para Barth, a identidade não é algo fixo e pode ser modificada de acordo com interesses ou mudanças de critérios de identidade e isso não abala o grupo.

Ambas as perspectivas não abrem espaço para categorias como perda cultural, assimilação e integração.

Para entender o movimento de reorganização social Krenyê e as tentativas de obtenção de reconhecimento político e territorial, procuramos refazer o percurso histórico dos Krenyê nos diferentes contextos econômicos, sociais e políticos em que estiveram inseridos e nas diferentes relações por eles estabelecidas, a partir do processo de dispersão que se deu em meados do século XX até os dias atuais.

Importante ressaltar que tal movimento é povoado por disputas, tensões e conflitos. Dentro desse campo de disputas entram em cena não só os Krenyê, mas agentes do Estado, entidades religiosas e diferentes povos com os quais estão em contato. A análise dos elementos constitutivos desse processo demonstra um campo de disputa entre os domínios territoriais e identitários.

As análises e resultados aqui apresentados são parte dos trabalhos de conclusão de curso de pós-graduação desenvolvidos pelos autores, um por ocasião da elaboração de dissertação de mestrado e outro tese de doutorado. De modo que as pesquisas que deram suporte a este artigo foram realizadas em momentos diferentes: uma parte da pesquisa foi realizada entre os anos de 2013 a 2014, e outra parte entre os anos de 2015 e 2016.

A principal forma de acessar o universo de pesquisa se deu por meio de trabalho etnográfico nos locais em que vivem os Krenyê que estão à frente do movimento político de demanda por reconhecimento, mais precisamente aqueles que vivem no município de Barra do Corda.

Além da pesquisa de campo nos locais em que os Krenyê vivem, outras ocasiões serviram à análise aqui realizada: observações em reuniões junto a instituições do Estado, encontros e seminários de diversas ordens. Além do acesso a notícias em mídias impressa ou digital a respeito dos Krenyê.

\section{Quem são os Krenyê hoje?}

A partir do trabalho de Nimuendajú (1946), os Krenyê foram divididos em dois grupos: os "Krenyê de Bacabal” e os "Krenyê de Cajuapará”. Esse autor acreditava que se tratava de dois povos distintos conhecidos pelo mesmo etnônimo. Os Krenyê de Bacabal, segundo ele, assemelham-se aos Timbira de Araparytiua, os do Cajuapará parecem mais com os Krepumkateyê e Pükob'gateyê'.

Segundo Nimuendajú (1946), os Krenyê do Cajuapará, no século XIX, vagavam próximo ao rio Gurupi e Pindaré, vivendo próximos aos Krikati e Gavião Pükob'gateyê'; e que estes, embora se autodenominem Krenyê, os "Krenyê do Cajuapára" são conhecidos por outros Timbira como Pivócasmecras e Pivocas. A sua área seria no Envira Branca, um igarapé que desemboca no Tocantins pela margem direita, um pouco abaixo da cidade Imperatriz.

Os chamados "Krenyê de Bacabal”, a que este artigo se refere, estão entre os povos que juntamente com os Pobzé e os Kukoéka- 
mekrá Francisco de Paula Ribeiro denominou "Timbira do Baixo Mearim" (1841). No início do século XIX, vagavam por entre o baixo rio Mearim e o baixo rio Grajaú, "tendo suas povoações estabelecidas a oeste do Pindaré" (RIBEIR0, 1841, p. 193).

Krenyê, atualmente, é um grupo representado por pessoas ligadas por meio de laços de parentesco. Um levantamento feito pela Fundação Nacional do Índio (FUNAI), através do grupo de trabalho para constituição da terra, aponta que existem por volta de 170 Krenyê. Todos se localizam geograficamente no estado do Maranhão, espalhados por diferentes regiões.

Os dois mais idosos Krenyê representam figuras importantes no processo de demanda por reconhecimento, visto que suas histórias e memórias sobre o território invadido ajudou no processo de reorganização social.

Atualmente, os Krenyê permanecem fragmentados vivendo em diferentes localidades. Aqueles que iniciaram e lideram o movimento de "luta por reconhecimento" identitário e territorial, vivem no município de Barra do Corda-MA, também de forma fragmentada.

Alguns habitam, desde 2010, uma chácara, afastada do centro da cidade, denominada aldeia São Francisco. A chácara foi comprada com o dinheiro da aposentadoria de um dos idosos do grupo, um senhor de 74 anos. Esta foi uma alternativa à vida "sufocada" da cidade. Entretanto a chácara de 1 hectare não apresenta possibilida- des de prover seus próprios sustentos. Outros moram em bairros na periferia da cidade de Barra do Corda, expostos à criminalidade e violência existentes na cidade. Há ainda alguns habitando uma aldeia na Terra Indígena (TI) Rodeador.

Há também grupos vivendo no município de Santa Inês e no município de Buriticupu. Outros estão na TI Pindaré, dos Tentehar; na TI Governador, dos Pükob'gateyê'; na TIKrikati, dos Krikati; e na TI Geralda Toco Preto dos Krepumkateyê.

Apesar de viverem de forma fragmetada e espalhada por diferentes localidades consideram-se parte de um mesmo povo.

\section{Trajetórias, processo de territorialização e construção do sentido de território do povo Krenyê}

0 processo de expropriação territorial dos Krenyê tem profunda relação com o processo de colonização brasileira, cuja violência atingiu não apenas esse povo, mas outros povos indígenas do Brasil. Pacheco de Oliveira (1998) aponta que se torna necessário compreender "um fato histórico- a presença colonial - que instaura uma nova relação da sociedade com o território, deflagrando transformações em múltiplos níveis de sua existência sociocultural" (OLIVEIRA, 1998, p. 8).

Portanto, faz-se necessário, no tratamento com a "situação histórica"4 (OLIVEI-

\footnotetext{
4. A noção de "situação histórica”, trabalhada por Oliveira (2015), visa entender a relação dos povos indígenas com diferentes agências de contato - de caráter governamental, religioso, desenvolvimentista, etc , observando a dinâmica do campo indigenista e as relações estabelecidas entre estes diferentes atores nele presente. 0 autor sugere que determinados atores são capazes de "produzir certa ordem política através da imposição de interesses, valores, e padrões organizativos sobre os outros componentes da cena política" (OLIVEIRA, 2015, p.49). Oliveira alerta para o fato de que a noção de "situação histórica" "não se confunde com a ideia historicista de fases", "não se refere basicamente a fatos e periodos, mas a modelos de distribuição de poder entre diversos atores sociais” (OLIVEIRA, 2015, p.49).
} 
RA, 1998) específica dos Krenyê, que nos desvencilhemos de concepções que estejam submetidas a limites geográficos ou mesmo a preconcepções que subsumam a análise de grupos étnicos como grupos formalmente estruturados e aldeados. Pacheco de Oliveira (1981) adverte para a necessidade nesses casos em que o trabalho do etnógrafo se volta para a observação de um "grupo" em mudança -, de que ele não se prenda ao padrão tradicional de descrição etnográfica.

Essa percepção é central neste trabalho, pois no processo de desacostumar o olhar no acompanhamento dos Krenyê fica explicitado o modo através do qual esse povo, mesmo passando por processos diversos de territorialização, tem como elemento central a profunda materialidade de suas relações simbólicas, que dependem das "situações históricas” específicas impostas pelas condições da "expansão do capitalismo nas áreas rurais periféricas e de articulação e subordinação de suas atividades econômicas, políticas e sociais aos interesses e estratégias de outras categorias e classes sociais" (OLIVEIRA, 1981, p. 277-278).

Os povos indígenas, no Brasil, foram submetidos a ações religiosas, militares e do aparato administrativo estatal que buscaram impor-lhes formas de territorialização. Mas, eles criaram formas próprias de resistência e, portanto, a territorialização não pode ser compreendida de modo homogêneo apenas em sua face de imposição vertical. Pacheco de Oliveira (1998, p.14) afırma:

0 processo de territorialização não deve jamais ser entendido simplesmente como de mão única, dirigido externamente e homogeneizador, pois a sua atualização pelos indígenas conduz justamente ao contrário, isto é, à construção de uma identidade étnica individualizada daquela comunidade em face de todo o conjunto genérico de "indios do Nordeste".

Para esse autor, territorialização é um conceito relacionado

a criação de uma nova unidade sociocultural mediante o estabelecimento de uma identidade étnica diferenciadora; 2) a constituição de mecanismos políticos especializados; 3) a redefinição do controle social sobre os recursos ambientais; 4) a reelaboração da cultura e da relação com o passado. (OLIVEIRA, 1998, p. 14)

Os Krenyê sofreram diferentes processos de "territorialização". Consideramos a submissão à Colônia Leopoldina como seu primeiro processo de "territorialização", pois levou a mudanças em diferentes aspectos da sua vida: trabalho, família, formas de sociabilidade e moradia, além de interferir em suas formas de expressão simbólica e identitária.

0 segundo processo de "territorialização" é caracterizado pelas invasões a seu território, por frentes de expansão e criadores de gado, na primeira metade do século XIX; na segunda metade do mesmo século, por imigrantes fugidos da seca que assolava o Nordeste brasileiro e pela fixação de moradia por parte dos invasores.

As invasões os levaram a deslocamentos em diferentes direções, impossibilitando uma vida coletiva e traçando trajetórias individuais alterando, assim, profundamente sua forma de organização social.

Sobre os deslocamentos, o mais idoso Krenyê morador da aldeia São Francisco, conta que teve que aprender com os Tentehar a construir sua própria casa com cavaco de madeira, técnica construtiva que não conhecia. Havia casado, pela segunda 
vez, com a filha de um cacique da TI Cana Brava e este, por sua vez, designou uma área desabitada para morarem, onde futuramente seria a aldeia Cocalinho:

Aí eu fui morar com a filha do cacique, ele disse: agora tu tá com minha filha, eu vou fazer uma aldeia pra vocês, que é onde é hoje o Cocalinho (aldeia), pois quem fez a abertura lá foi eu. Ele me levou lá me mostrou e aí nós fumo tirar cavaco, eu nem sabia tirar ele me ensinou e nós fizemos uma casa, depois da casa feita ele disse agora nós vamos fazer uma roça pra você, eu tenho outro genro e vou ajeitar pra ele vir morar com vocês, pra vocês não ficar sozinho. (F. Krenyê $\hat{e}^{5}$, idoso morador da aldeia São Francisco $^{6}$, grifo nosso)

No estudo sobre os Krenyê, assim como sobre outros povos indígenas no Brasil, há algumas noções que são centrais, como as de terra e território. Em sua trajetória de luta, os Krenyê sofreram diversos processos de deslocamentos violentos, portanto o uso dessas noções faz-se necessário ao entendimento desse processo.

De acordo com Gallois (2004, p.5) "noção de "terra indígena" diz respeito ao processo jurídico-político conduzido sob a égide do Estado, enquanto a de "território" remete à construção e à vivência, culturalmente variável, da relação entre uma sociedade específica e sua base territorial”

A Constituição Brasileira, em seu art. 231 reconhece aos índios "os direitos originários sobre as terras que tradicionalmente ocupam”.
A dificuldade de garantia deste direito a esse povo, segundo o "Relatório Circunstanciado de Constituição da Reserva Indígena Krenyê" (2015, p.37), assenta-se na ausência do território:

As TI's habitadas atualmente pela população de índios Krenyê são de ocupação tradicional de outras etnias, o que, conforme já foi dito, vem dificultar a sua sobrevivência física e cultural. Baseando-se nos preceitos do artigo 231 da Constituição Federal de 1988, observa-se essa dificuldade em fatores como: a) não garantia do usufruto exclusivo dos recursos naturais; b) dificuldade em expressar plenamente seus usos, costumes e tradições pela convivência com povos de culturas diferentes nas terras onde vivem; c) abalo na autonomia de sua organização comunitária pelo confronto com outras organizações sociais. Por fım, a ausência de território tem comprometido a segurança alimentar deste povo.

Ocorreram, no caso dos Krenyê, violações diversas de direitos, ao longo de sua história, levando-os a diferentes processos de "territorialização" (OLIVEIRA, 1998). Isso coloca ao Estado brasileiro o desafio de reconhecimento e demarcação de uma "terra indígena”, "enquanto processo político-jurídico" (GALLOIS, 2004).

Vale ressaltar que a concretização dessa unidade administrativa, através da concessão do direito à "terra indígena", deve, necessariamente, remeter-se ao sentido que os Krenyê dão ao território - compreendido como seu modo de criar, fazer e viver, que se

5. Decidimos preservar a identidade dos atores citados neste trabalho, revelando apenas a primeira letra do nome ou o nome indígena.

6. Relato feito a Figueiredo em 2015. 
constituem elementos fundamentais para sua reprodução física e cultural.

Assim, o território não pode ser visto apenas como um espaço geográfico ocupado, pois como coloca Haesbaert

0 território envolve sempre, ao mesmo tempo [...], uma dimensão simbólica, cultural, por meio de uma identidade territorial atribuída pelos grupos sociais, como forma de controle simbólico sobre o espaço onde vivem (sendo também, portanto, uma forma de apropriação), e uma dimensão mais concreta, de caráter político disciplinar: a apropriação e ordenação do espaço como forma de domínio e disciplinarização dos indivíduos (HAESBAERT, 1997, p.42)

No caso dos Krenyê, o não acesso à "terra indígena" como garantia político-jurídica, não significou a anulação do sentido de território construído por eles, assim "o território antes de se exprimir por uma ligação a um lugar particular, é uma relação entre pessoas e se refere à organização do espaço carregada de história” (GODOI, 2014, p. 441).

No Relatório Circunstanciado de Constituição da Reserva Indígena Krenyê (2015, p.41) há a seguinte afirmação:

A grande maioria dos índios Krenyê que ainda se encontram vivos não tiveram a oportunidade de viver em seu território ancestral, na bacia dos Rios Mearim e Itapecuru, exceto os mais velhos, como Dona Maria de Lurdes e Seu Chico, que viveram os primeiros anos de vida na Pedra de Salgado e possuem algumas lembranças do território que habitavam, já que passaram a maior parte de suas vidas transitando em outras TI's e até mesmo fora delas, como nas circunstâncias atuais em que moram na periferia da cidade de Barra do Corda.

A partir dessa afırmação, constata-se a ideia de que é produzida uma construção coletiva do sentido de território e de pertencimento a um lugar, que é comum aos Krenyê, e que está na memória que perpassa o povo, mesmo tendo vivenciado violentos processos de espoliação territorial. Nesse sentido, eles possuem lembranças do território que habitavam, mesmo tendo passado a maior parte de suas vidas transitando em diversas terras indígenas.

A memória que perpassa uma parcela do povo $^{7}$ é construída a partir da memória dos anciãos, pois embora muitos não tenham vivido no "território tradicional" constroem vínculo com ele e se veem representados pelas lembranças daqueles que lá viveram. Assim, as memórias dos mais velhos ajudam a construir e recuperar o que Bartolomé (2006) chama de a coletividade étnica de pertencimento.

Para compreender toda a tecitura territorial por onde os Krenyê, ao longo de sua trajetória, foram enveredando, foi necessário fazer esse percurso através da escuta de suas vozes, de suas lembranças e memórias. Mesmo que, aos ouvidos incautos, essas vozes e memórias, pareçam fragmentadas, desconexas e sem uma sequência cronológica coerente, foi preciso estar atento para compreender as entrelinhas dos discursos e não ser conduzido a procurar uma linearidade historicista dos fatos.

Walter Benjamin (1987) nos ajuda nessa escuta atenta e entendimento de narrativas. A partir de Benjamin (1987) compreen- 
demos que "Articular historicamente o passado não significa conhecê-lo 'como ele de fato foi'. Significa apropriar-se de uma reminiscência, tal como ela relampeja no momento de perigo" (BENJAMIN, 1987, p.224).

Os depoimentos dados ora aos pesqui- sadores, ora ao Ministério Público Federal ou a cinegrafistas e jornalistas, revelam os diferentes mecanismos e acontecimentos que inviabilizaram ou contribuíram para a vida dos Krenyê, nas diferentes terras por onde passaram.

Quadro 1 - Terras Indígenas habitadas pelos Krenyê

\begin{tabular}{|c|c|c|c|c|c|}
\hline T.I & $\begin{array}{l}\text { Povo à qual } \\
\text { pertence }\end{array}$ & $\begin{array}{l}\text { Tronco } \\
\text { Linguístico/ } \\
\text { Lingua }\end{array}$ & População & $\begin{array}{l}\text { Situação } \\
\text { Fundiária }\end{array}$ & $\begin{array}{l}\text { Municipios de } \\
\text { Abrangência }\end{array}$ \\
\hline Rio Pindaré & $\begin{array}{l}\text { Tentehar - } \\
\text { Guajajara }\end{array}$ & Tupi/ Tentehar & 775 & Homologada & $\begin{array}{l}\text { Monção e Bom } \\
\text { Jardim }\end{array}$ \\
\hline Governador & $\begin{array}{l}\text { Pükob'gateyê - } \\
\text { Gavião }\end{array}$ & $\begin{array}{l}\text { Macro-Jê/ } \\
\text { Timbira }\end{array}$ & 1.058 & Homologada & Amarante \\
\hline Rodeador & $\begin{array}{l}\text { Tentehar - } \\
\text { Guajajara }\end{array}$ & Tupi/ Tentehar & 683 & Homologada & Barra do Corda \\
\hline Canabrava & $\begin{array}{l}\text { Tentehar - } \\
\text { Guajajara }\end{array}$ & Tupi/ Tentehar & 7.158 & Homologada & $\begin{array}{l}\text { Barra do Corda, } \\
\text { Jenipapo dos Vieiras } \\
\text { e Grajaú }\end{array}$ \\
\hline $\begin{array}{l}\text { Geralda } \\
\text { Toco Preto }\end{array}$ & Krepumkateyê & $\begin{array}{l}\text { Macro-Jê/ } \\
\text { Timbira }\end{array}$ & 163 & Homologada & Itaipava do Grajaú \\
\hline Krikati & $\begin{array}{l}\text { Pükob'gateyê - } \\
\text { Gavião }\end{array}$ & $\begin{array}{l}\text { Macro-Jê/ } \\
\text { Timbira }\end{array}$ & 1.700 & Homologada & $\begin{array}{l}\text { Montes Altos, } \\
\text { Sítio Novo, Amarante } \\
\text { e Lajeado Novo }\end{array}$ \\
\hline
\end{tabular}

Fonte: IBGE, Censo 2010. Elaboração Figueiredo.

Conforme se observa no quadro acima, os Krenyê passaram por diversas terras indígenas, diferentes paisagens e ecossistemas onde ocorreram casamentos de alguns de seus membros com integrantes de povos indígenas de diferentes troncos linguísticos.

Antes destes deslocamentos entre as diferentes "terras", os Krenyê viviam em uma região conhecida como "Pedra do Salgado", viveram nesta área, até aproximadamente as décadas de 1940 e 1960. A Pedra do Salgado está localizada na região próxima a Bacabal. 0 local tem esse nome devido à existência de um morro rochoso de coloração esbranqui- çada, porém, desde a década de 1960, vem sendo destruído para retirada de pedras utilizadas em pavimentação de estradas.

Hoje, a Pedra do Salgado dá nome a um dos povoados pertencentes ao município de Vitorino Freire e tem cerca de 1.800 habitantes. Além da referência como ponto de identificação geográfica, essa enorme pedra está na memória dos Krenyê mais velhos como um local sagrado, pois conforme relata M. Krenyê, sua mãe contava que quando algum índio adoecia, quando ainda estavam nessa região, era só colocar a mão na pedra que ficava bem. 
A saída de parte dos atuais Krenyê da região a qual eles se referem como Pedra do Salgado $^{8}$ foi consolidada entre os anos 1940 e 1960, motivada por dois fatores, conforme demonstram os relatos e fontes historiográficas: primeiro, foi a crescente ocupação por migrantes nordestinos na região do rio Mearim, que ocasionou consequências diretas sobre as populações indígenas remanescentes. Sobre essa situação Da Costa (2006) relata:

Entre o final da década de 1930 até a década de 1960, constituiu-se a fase áurea da economia regional de Bacabal. 0 carro chefe foi uma indústria francesa, estabelecida na cidade vizinha de São Luis Gonzaga, que se dedicava à compra e venda de algodão, exportado através da hidrovia do rio Mearim. Em razão da Segunda Guerra Mundial, o Cotoniére Brasil Cia Ltda. foi vendida para a empresa brasileira Chames Aboud e Companhia, de propriedade de Wady Aboud e seus filhos César e Alberto Aboud. Em função desse movimento, Bacabal tornou-se centro comercial e de produção, com um porto de muito movimento, atraindo muitos migrantes nordestinos. A firma dos Aboud possuía filial em Bacabal. Em 1931 foi inaugurada a iluminação elétrica, com sua primeira usina substituída por outra mais possante, estando atualmente, sob responsabilidade das Centrais Elétricas do Maranhão - CEMAR. (DA COSTA, 2006)

As principais informações sobre a saída dos Krenyê da Pedra do Salgado foram dadas por dois anciãos Krenyê - um casal de irmãos, por serem os mais velhos e terem participado desse deslocamento inicial, quando crianças.

Nos relatos dos Krenyê mais velhos, quando recuperam suas histórias desse período da Pedra do Salgado, falam sobre a crescente ocupação por migrantes nordestinos $^{9}$, a quem os Krenyê denominam genericamente de cearenses:

Todo dia chegava os fregueses (não índios) lá enchendo a terrinha, e fazendeiro já tinha cercado tudo lá. Esse fazendeiro era rico mesmo, que é esse... Antônio Tavera, o irmão conhece aí (...) Quebrava coco era de noite, de noite que os "cearense" quebravam coco. De noite que os "cearense" quebravam coco, a noite toda. E aquelas velhas torrando coco e fazendo sabão, e assim, as "cearense fêmea”, assim, mocinha passava era o dia todinho com aqueles chapeuzão na cabeça. Ora não! No cabo mesmo da enxada. (M. Krenyê, idosa moradora da aldeia São Francisco ${ }^{10}$ )

8. Nesse sentido, ratifico a ideia de Little (2002, p.263), apoiado em Deloria 1994; Sack (1980), quando postula que "a identificação de lugares sagrados por um grupo determinado representa uma das formas mais importantes de dotar um espaço com sentimento e significado, porém existe uma multiplicidade de outras".

9. Sobre esse processo de migração em massa para o Maranhão nas primeiras décadas do século XX, ocasionando uma frente de expansão agrícola, Velho (2013, p.89) analisa que os nordestinos iniciaram essa penetração em regiões maranhenses "em busca de terras e fugindo das secas e das dificuldades de colocação da mão - de - obra no próprio Nordeste. Atravessam o Paranaíba em Teresina e Floriano, e a princípio vinham também por mar. Praticavam uma agricultura de subsistência e, em graus variáveis, a do arroz com finalidades comerciais. É uma hipótese plausivel que a decadência da exploração da borracha amazônica tenha estimulado o movimento nessa direção a partir de 1920, o que evitará a interrupção do fluxo de nordestinos que já estava se dando e lhe dará uma nova forma que constituirá um marco significativo nas transformações da exploração agropecuária no Brasil. É também o que emprestará ao Maranhão sua feição atual tão marcadamente agrícola”.

10. Trecho retirado do Relatóio Circunstanciado de Constituição da Reserva Indigena Krenyê, 2015, p.18 
0 segundo fator que causou a dispersão dos Krenyê, entre as décadas de 1930 a 1960, da região conhecida como Pedra do Salgado, no médio Mearim, foi o surto de sarampo pelo qual foram acometidos, provocando grande mortandade nesse povo. Os sobreviventes se refugiaram em áreas onde atualmente são as terras indigenas dos Krepumkateyê (TI Geralda) e dos Tentehar (TI Pindaré), conforme informações contidas na Informação Técnica $\mathrm{n}^{\circ}$ 067/CGID/FUNAI - 2012:

\section{A dispersão do Grupo Krenyê, de acordo com a memória oral dos indígenas, aconteceu na década de 1930, quando o grupo começou a deixar a região do Bacabal, também conhe- cida como Baixo Mearim, por força de uma epidemia de sarampo. [Estes foram] encami- nhados pelo chefe da colônia Leopoldina, o grupo se dividiu em dois: uma parte ocupou a área hoje correspondente à TI Geralda To- co Preto e a outra a região da aldeia Januá- ria, hoje TI Rio Pindaré, de ocupação Guaja- jara. Inicialmente perfazendo um total de 08 famílias, os Krenyê permaneceram na TI Rio Pindaré por mais de 40 anos.}

Também sobre essa situação de deslocamento por conta da epidemia, coligimos diversos depoimentos que demonstram os processos de desagregação e dispersão dos Krenyê mediante tal mortandade, provocada pela epidemia de sarampo:

0 meu povo era assim, não tinha quem cuidasse, aí era muito índio, mas adoeceram de sarampo, aí comia tudo enquanto do mato, (...) todo bicho do mato comia, aí foram morrendo, morrendo, se acabando, se acabando, até que se acabou a metade mesmo, ficou, morreram tudo... (M. Krenyê $\hat{e}^{11}$, idosa moradora da aldeia São Francisco)

Saímos de lá (da Pedra do Salgado) por causa que tava morrendo muito (...). Podia cavar buraco de noite pra enterrar amanhã. Morria de sarampo. Nessa época eles criava muito porco, e aí (...). Nessa época não tinha quem cuidava da gente, vocês mesmo, essa época não tinha pessoa pra cuidar, né. Aí era o jeito morrer, não era? (F. Krenyê, idoso morador da aldeia São Francisco ${ }^{12}$ )

Nessas falas são evidenciados alguns aspectos importantes para reflexão. Um, diz respeito à questão da falta de assistência na época do surto epidêmico ${ }^{13}$, reclamada por ambos idosos. Outro aspecto é quanto à ques-

11. Depoimento concedido ao Ministério Público Federal-MA, 2010.

12. Depoimento concedido ao Ministério Público Federal-MA, 2010.

13. Quanto à questão dos surtos de epidemias que assolavam diversos povos indígenas, mesmo no início do século XX, ver livro publicado pelo MEC (Ministério da Educação) em parceria com UNESCO (Organização das Nações Unidas para a Educação, a Ciência e a Cultura), de autoria de João Pacheco de Oliveira e Carlos Augusto da Rocha Freire,que é esclarecedor no que se refere a essas epidemias e que ilustra bem a situação dos Krenyê à época: "O contágio da variola, gripe, tuberculose, pneumonia, coqueluche, sarampo e outras viroses levaram à dizimação de inúmeros povos indígenas, à mortandade de milhares de índios (...). Nas primeiras décadas do século XX, essa realidade não foi alterada: nos grupos recém-contatados pelo SPI, aldeias inteiras foram destruídas por doenças pulmonares (...). 0 SPI dificilmente conseguia controlar, estabilizar e melhorar a condição sanitária de povos indígenas que enfrentavam surtos epidêmicos. Em campo, no início dos anos 50, o antropólogo Darcy Ribeiro foi testemunha da morte de dezenas de índios Urubu Kaapor dizimados por sarampo e coqueluche (OLIVEIRA; FREIRE, 2006, p. 123). Os postos indígenas possuiam alguns medicamentos, mas a maioria de seus encarregados era leiga em assistência sanitária". 
tão de um possível agravamento da doença por conta da ingestão de alimentos tidos como "reimosos", pois comiam tudo "enquanto do mato, (...) todo bicho do mato comia (...)”, pois dada as forças das circunstâncias era impossivel fazerem os devidos resguardos e manterem seus tabus alimentares ${ }^{14}$.

Quanto à questão da falta de assistência, vale lembrar que nesse período o principal órgão de assistência aos povos indígenas no Brasil era o Serviço de Proteção ao Índio (SPI), cuja política de atendimento foi marcada por contradições denominadas “paradoxos indigenistas” (OLIVEIRA, 1998). Se em tese objetivava proteger os povos indígenas e as suas terras, na prática agia ao contrário, realizando a transferência de índios e a liberação de territórios indígenas para a colonização. As principais iniciativas desse órgão, estavam voltadas para a pacificação e sedentarização de povos indígenas em áreas de recente colonização.

0 avanço das frentes de expansão, aliado ao surto de epidemias nessa região do rio Mearim, provocaram não só a saída dos Krenyê e a sua busca por abrigo em outras terras indígenas, como a desagregação social de diferentes povos Timbira, conforme atesta Ribeiro (1982):

Em fins do século passado quase todas as terras aproveitáveis já estavam controladas pelos criadores de gado. Os grupos Timbira que não quiseram submeter-se tiveram de abandonar os campos fugindo para as matas [...] com o tempo, vitimados pelas doenças e pela miséria, resultante, em parte, da redução do seu território de caça e de coleta os Timbira que ficaram nos campos diminuíram tanto que nem puderam mais fazer face à invasão dos poucos campos que lhes foram reservados quando da pacificação. À custa de tramóias, de ameaças e de chacinas, os criadores de gado espoliaram a maioria deles e os remanescentes de vários grupos se viram obrigados a juntar-se nas terras que lhes restavam, insuficientes para o provimento da subsistência à base de caça, da coleta e da agricultura supletiva desses índios. (RIBEIRO, 1982, p.63)

A saída dos Krenyê da Pedra do Salgado, região do Mearim, para a região do rio Pindaré, deu-se através da intervenção direta do SPI. Tal fato é recorrente nas falas dos Krenyê mais velhos que vivenciaram essa experiência.

Nos depoimentos sobre esse deslocamento surge sempre a figura do Doutor Xerez (Sebastião Xerez), um advogado amazonense, de orientação positivista, que foi o responsável pela $3^{\text {a }}$ Inspetoria do SPI no Maranhão entre os anos de 1948 a 1962:

Aí meu tio, ele agora já morreu, faz tempo que ele morreu, aí ele disse: "agora vocês ficam aqui, que eu vou caçar outro lugar para nós”. Aí ele saiu, foi pra São Luís, nesse tempo foi pra São Luís pra lá, foi no tempo do Xerez, o povo diz que esse Xerez não é mais vivo. Aí diz que o doutor Xerez botou ele pra cá pro Pindaré. Aí arrumou tudo pra

14. Sobre a questão relativa aos tabus alimentares é comum os indígenas classificarem os alimentos em dois tipos: os não-reimosos e os reimosos. Os não-reimosos são os que se podem comer sem restrições. Os reimosos seriam aqueles que causam mal ao organismo, que podem provocar doenças ou agravar as que já estão instaladas no corpo e que devem ser evitados durante o período de resguardo e menstruação das mulheres ou quando se está doente. Dentre os alimentos reimosos mais comuns estão alguns tipos de caça, carne de porco e de pato, peixes de couro e diversas frutas, principalmente as azedas. 
lá pra ele, aí botou nós pra cá pro Pindaré. Já veio bem pouquinho, já tinha morrido a metade. (M. Krenyê, idosa moradora da aldeia São Francisco ${ }^{15}$ )

No mesmo sentido se coloca a fala do seu irmão:

Nesse tempo, era o tempo do SPI, então quem mandava lá era o Dr. Xerez. Aí o Dr. Xerez disse pra ele: Olha, Maximiano, eu não conheço lá onde vocês moram como de vocês, né? Eu conheço lá no Pindaré e na Geralda, né? Agora aí você escolhe se você quer ir prá Geralda, aí você vai. Se não quiser ir, aí você vai pro Pindaré (...) lá que agente conhece que é de vocês, né? (F. Krenyê, idoso morador da aldeia São Francisco ${ }^{16}$ )

Observa-se nos depoimentos que o SPI ofereceu duas opções de deslocamento para o Maximiniano Krenyê, o tio dos dois idosos. 0 Dr. Xerez teria colocado como alternativas de refúgio, a Geralda ${ }^{17}$ e o Pindaré $^{18}$. Tais informações são corroboradas pela análise feita por Gomes (2002) nos documentos do SPI, dando conta que:

Em 1960, umas poucas famílias dos índios Timbira do baixo Mearim, (os antigos Pobzés e Crenzés) pediram ajuda ao SPI, e Xerez, sem condições de criar um posto para eles e demarcar terras, estando tão próximo da crescente cidade de Bacabal, achou por bem instalá-los nas terras do posto Gonçalves Dias. Os desolados Timbira vieram e passaram a conviver com os Tenetehara, quase sempre em desconfiança mútua e às vezes com alguma agressividade. Alguns Timbira até que tentaram situar uma aldeia no médio Pindaré, no lugar Mineiro Grande, mas a chegada de tantos invasores os fez recuar para as terras ao redor do posto. Todavia, nenhum desentendimento atávico impediu que, no processo de expulsão de invasores, os Timbira fossem de crucial importância, auxiliando os Tenetehara de todos os modos possiveis, e em alguns casos com riscos de vida. (GOMES, 2002, p.302)

As lembranças desse deslocamento ainda estão bastante vivas na memória dos Krenyê que, mesmo sendo crianças na época, relatam como foi a saída da Pedra do Salgado para aldeia Januária: Olha, nós viemos de lá da Pedra do Salgado
pra chegar bem aí no Ajenuário [aldeia Ja-
nuária]. Nós viemos foi de pé, só meu irmão
menor que veio montado num jumento. Meu
padrasto comprou dois jumentos, um macho
e uma fêmea, aí nós viemos. É... nesse tem-
po, a criança que nós trouxemos de lá que
era pequena, foi o finado Riba. Ele era pe-
queno. Só ele que minha mãe botava ele pra
vim montado no meio da carga. Aí nós vie-

15. Depoimento concedido ao Ministério Público Federal-MA, 2010.

16. Trecho retirado do vídeo do I Encontro do Povo Krenyê, 2009.

17. Na aldeia Geralda viviam e ainda vivem os Krepumkateyê, povo de língua Jê, e está localizada no Município de Itaipava do Grajaú no sertão Maranhense, entre os municípios de Grajaú e Barra do Corda. Atualmente essa aldeia é denominada Geralda-Toco Preto, devido à união dessas duas aldeias e fica dentro da terra indígena com o mesmo nome.

18. 0 Pindaré referido nos depoimentos é a T. I. Pindaré, pertencente aos Tentehar, falantes de língua Tupi, cuja aldeia principal é a Januária, que foi o local para onde os Krenyê foram deslocados. 
mos de lá pra cá. De lá da Pedra do Salgado pra cá pro Ajenuário. Nós passamos um mês e cinco dias. Quando nós passamos um mês e cinco dias... quando inteirou os cinco dias, nós chegamos lá na beira do rio (Pindaré) do Ajenuário, uma hora da tarde. Eu era pequena, mas eu me lembro. Aí um mês e cinco dias chegamos lá na beira do rio do Ajenuário. Aí meu padrasto gritou: ei caçador! Aí veio um índio, atravessou nós pro lado de lá, e meu tio veio. Era, o índio era Guajajara. Agora o outro era meu tio. Aí ele veio. Ai ajudou a levar a bagagem. E atravessaram o jumentinho. Aí nós ficamos lá. (M. Krenyê, idosa moradora da aldeia São Francisco ${ }^{19}$ )

Após a saída da Pedra do Salgado, o SPI, através da diretoria local de São Luís, deslocou os Krenyê para a TI Pindaré. Depois de algum tempo de convivência e de alguns casamentos com Tentehar, esses anfitriões designaram uma área, conhecida como Tirirical, na divisa da terra indígena, para estabelecerem a aldeia dos Krenyê.

É aquela mesma história por onde a gente já passou por essas diversas comunidades e povo, eles sempre diziam assim: "olha vocês como povo, vocês também são um povo, então, não vão ficar aqui no nosso meio". Aí entregava uma área, como nesse período (da TI Pindaré), onde foi montada a primeira aldeia do povo Krenyê, mas já misturado, mas lá fora, na divisa. Então toda vida eles diziam isso: "olha vocês são de um povo, aí vocês vão, situam, fazem uma aldeia prá vocês". E foi onde nós ficamos, ficamos lá fo- ra da aldeia dos Tentehar, lá distante.” (R. Krenyê, liderança à frente do movimento de luta por reconhecimento Krenyê, morador da aldeia São Francisco ${ }^{20}$ )

Nessa narrativa é relevante observar uma questão de fundo - o fato dos Krenyê, apesar de misturados com outros povos, serem vistos com distinção, quando o assunto é a sua situação territorial. Sendo visto como povo, diferenciado, deveriam, portanto, ficar em outra área, de preferência distante das aldeias dos Tentehar, na divisa da terra, em local fronteiriço, o que não implica simplesmente em uma fronteira geográfica, física. Isso nos remete à ideia de Barth (2000) nos seus estudos sobre etnicidade e construção de fronteiras entre os grupos étnicos, que afırma:

As fronteiras sobre as quais devemos concentrar nossa atenção são evidentemente fronteiras sociais, ainda que possam ter contrapartida territorial. Se um grupo mantém sua identidade quando seus membros interagem com outros, disso decorre a existência de critérios para determinação do pertencimento, assim como as maneiras de assinalar este pertencimento ou exclusão. Os grupos étnicos não são apenas ou necessariamente baseados na ocupação de territórios exclusivos; e as diferentes maneiras através das quais eles são mantidos, não só as formas de recrutamento definitivo como também os modos de expressão e validação contínuas devem ser analisadas. (BARTH, 2000, p. 34)

19. Trecho retirado do Relatório Circunstanciado de Constituição da Reserva Indígena Krenyê, 2015.

20. Discurso proferido ao pesquisador Figueiredo em 2015. 
Foi durante esse período que estiveram na TI Pindaré, que os Krenyê aprenderam, minimamente, a língua dos Tentehar e diferentes técnicas de caça e pesca, e vários membros do grupo casaram-se com Tentehar. No entanto, apesar das relações interétnicas estabelecidas, os Krenyê relatam certa hostilidade por parte dos Tentehar em relação a eles, além de ameaças de expulsão:

Aí os Guajajara falavam: "é bom vocês procurar o lugar de vocês” (...). Porque os meus parentes era negócio de trabalhar assim de roça, né. Aí parece que eles criaram inveja, aí botaram quente assim na gente (...). Eu tenho uma menina lá ainda, né, da primeira mulher. (F. Krenyê, idoso morador da aldeia São Francisco ${ }^{21}$ )

Uma liderança Krenyê reforça essa ameaça:

Durante vinte anos, os Guajajaras ficavam mandando irmos embora do Pindaré. Depois de vinte anos, os mais velhos resolveram sair de lá. 0 povo sempre queria se juntar, mas nem sempre conseguiu. (R. Krenyê, liderança a frente do movimento de luta por reconhecimento Kreny $\hat{e}^{22}$ )

Foi nesse período que parte do Krenyê se deslocou para a TI Governador, do povo Gavião Pükob'gateyê', e outro núcleo de famílias permaneceu no TI Pindaré, encontrando-se nesse local até os dias atuais.
A saída de algumas famílias Krenyê da aldeia Januária para a TI Governador ${ }^{23}$ foi uma iniciativa que, segundo as informações coletadas durante o trabalho de campo, partiu de um Krenyê, que já convivia e havia se casado com uma Pükob'gateyê'-Gavião. Seu nome era AaruyZ. M.; visto, tanto por seus parentes, quanto por indigenistas e antropólogos, como uma grande liderança, chegou, inclusive, a ser cacique dos Pükob'gateyê'-Gavião, na aldeia Governador.

Aaruy Z. M. participou do movimento indígena nos anos 1980, destacando-se na luta travada contra grandes projetos de desenvolvimento, sobretudo aqueles ligados à Estrada de Ferro Carajás. Empreendeu várias viagens a Brasília e São Paulo, participando de diversos fóruns de debate sobre a política indigenista. Sobre essa intervenção de Z. M. no deslocamento para a TI Governador, os Krenyê narram que:

Foi o tempo que meu sobrinho, meu primo, irmão dela aí, finado Z. M pareceu lá aí pegou a mãe e o R. Krenyê e levou lá para o Governador. Aí eu fiquei sozinha mais a Isabel. Aí com muitos dias a mãe mandou o R. Krenyê atrás de nós, aí nós fomos. (M. Krenyê, idosa ${ }^{24}$ moradora da aldeia São Francisco)

0 deslocamento se deu de forma parcelada, primeiramente Z. M. levou sua tia Balbina e seu sobrinho R. Krenyê, respectivamente mãe e filho da idosa M. Krenyê.

21. Depoimento concedido ao Ministério Público Federal-MA, 2010.

22. Depoimento concedido ao Ministério Público Federal-MA, 2010.

23. A Terra Indigena Governador pertencente aos índios Pükob'gateyê-Gavião, povo de língua Timbira, situa-se em uma região de cerrado e floresta de transição amazônica, nas proximidades do município de Amarante do Maranhão. Atualmente conta com uma população de 1.058 pessoas (IBGE, 2010) e passa por um processo conturbado de ampliação de sua área.

24. Relato feito a pesquisadora Almeida em 2015, aldeia São Francisco. 
Posteriormente, foram seguidos por M. Krenyê e sua irmã I. Krenyê e A.L, à época seu marido. 0 seu enteado, adolescente, e que anos depois se tornaria figura importante no processo de reorganização política dos Krenyê, acompanhou o grupo no deslocamento.

F. Krenyê, que nessa época estava vivendo com sua família na TI Cana Brava, ao saber desse deslocamento para a TI Governador, decide acompanhá-los.

Aí dessa vez do acontecimento eu vivia era aqui mesmo, aqui no Cocalino. Eu fui passar uns tempo com minha mãe lá na Januária, foi o tempo que meu primo chegou e disse que ia arrecadar nós tudinho pra levar aí eu fui e disse pra mulher, pois então se for assim a gente vai. Disse que ela ia também. Aí eu fui mais ela passar esses tempo. (F. Krenyê, idoso morador da aldeia São Francisco ${ }^{25}$ )

Entretanto, não permaneceram muito tempo na Terra dos Gavião. 0 idoso Krenyê relata que houve um conflito com os Pükob'gateyê-Gavião, tendo sido alvejado com um tiro e que, segundo ele, o chumbo ainda estaria alojado em seu corpo. Nesse conflito, Z. M. também saiu ferido por colocar-se na disputa ao lado de seus parentes Krenyê.

Do primeiro ano aí a gente fez uma roça deu muita coisa, só que dessa roça nós não se lucremos de nada aí aconteceu um negócio co- migo, com inveja. Aí eles me deram, eles me coisaram aqui. Aí isso aqui foi um tiro aqui oi, lá. É porque nós cortemos um mucado de arroz é porque era vinte e poucas linhas. Era porque o meu primo [Z. M.] ele gostava de trabalhar também. Agora nós não trabalha porque não tem lugar pra plantar. Agora esse arroz ninguém.... ele baleou eu e meu primo, não é. [...] É por causa disso que eu não quero morar assim na aldeia dos outros não. É porque assim nós gosta de trabalhar nós gosta de criar pra qualquer pessoa que chegar assim vê o nosso trabalho. E também eu não queria ir mais assim pra aldeia dos outros assim não. Eu queria um negócio era assim nosso, nosso, nosso mesmo. (F. Krenyê, idoso morador da aldeia São Francisco ${ }^{26}$ )

Em outro momento, a sobrinha do Z. M. Aaruy, filha de Krenyê com Pükob'gateyêGavião, relata também sobre o conflito:

Z. M. (Aaruy) apesar de ser Krenyê, casouse com Gavião e levou seus parentes para lá, com um conflito interno eles foram expulsos da TI Governador, após terem sido baleados, tanto Z. M. quanto S. Chico. Após isso, foram para Rodeador em $1982^{27}$, tempos depois os sogros do Z. M. foram buscá-lo para voltar à TI Governador. (P. Krenyê, jovem Krenyê moradora da aldeia São Francisco ${ }^{28}$ )

Essa tentativa frustrada de "juntar o povo" na terra dos Pükob'gateyê'-Gavião quase termina em grande tragédia, por pouco

25. Relato concedido a pesquisadora Almeida, fevereiro de 2015 na aldeia São Francisco.

26. Relato concedido a pesquisadora Almeida, fevereiro de 2015 na aldeia São Francisco.

27. Segundo o antropólogo Adalberto Luiz Rizzo de Oliveira este deslocamento teria acontecido no ano de 1985. Ele esteve em Imperatriz nesse constexto da transferência para a Rodeador e pôde observar este processo (Relato feito a pesquisadora Almeida, 2017).

28. Relato concedido ao pesquisador Figueiredo em 2015. 
não aconteceram mortes dos dois Krenyê baleados que passaram por tratamento médico na cidade de Imperatriz.

Após este incidente com os Pükob'gateyê', a Funai teve a iniciativa de transferir os Krenyê para T. I. Rodeador ${ }^{29}$. De acordo com alguns relatos, essa permanência de algumas famílias Krenyê foi por pouco tempo, provavelmente entre 1985 e 1987 :

Eram cinco famílias, duas foram para Barra do Corda e três ficaram. Acharam ruim ficar sozinho porque ficaram com medo porque lá tinha muito mato, onça, cobra. Ficaram com medo. Tinha um peixe no porto que queria engolir uma índia, um surubim. Ficou um casal e um índio misturado com Guajajara, que acabou indo morando em Cachoeirinha. Ficou só o finado Z. M. (Aaruy) e sua esposa, que acabaram indo embora. (A. Timbira, cacique da aldeia Pedra Branca $^{30}$ )

Com a dispersão desse núcleo de famílias Krenyê da TI Rodeador, o Z. M. Aaruy retornou para a terra dos Pükob'gateyê'-Gavião, já em uma situação mais favorável de reconciliação, voltando à militância indígena nessa região. No entanto, foi assassinado em 1987, na cidade de Imperatriz, sob circunstâncias até hoje não esclarecidas. Há duas versões para sua morte: a que foi divulgada na imprensa da época, que afırma ter sido morto pela polícia e a outra, conta- da pelo Cacique I.Tentehar, da TI Araribóia, de que ele foi morto em uma tocaia armada por uma pessoa usuária de drogas, após um desentendimento com o mesmo na Coordenação Regional da Funai, em Imperatriz. Deixou quatro filhos, sendo que dois deles residem junto aos Pükob'gateyê até os dias atuais.

Sobre os desdobramentos desse assassinato, não obtivemos informações quanto à prisão ou julgamento de alguém, apenas que foi dada uma indenização à família de Z. M., que habita a TI Governador.

Com a saída de Aaruy da TI Rodeador, os Krenyê se dispersaram novamente, alguns voltaram para Santa Inês, próximo à TI Pindaré, outros para TI Cana Brava; e outros voltaram a morar na cidade de Barra do Corda.

Com a dispersão tiveram que passar por novas mudanças e adaptações e enfım tentativa de reorganização social. As narrativas sobre esse processo demonstram conflitos, tensões e é sobre esse movimento que passamos a tratar.

\section{Processo de reorganização social e luta por reconhecimento}

0 processo de demanda por reconhecimento da identidade étnica e direitos sociais e territoriais Krenyê data do início do século XXI. 0 enteado de M. Krenyê, A. Timbira, liderou este movimento de deman-

29. A T.I. Rodeador é uma terra dominial comprada em 1920 (COELHO, 1987) e transferida, pelo SPI em 1930 (LAVE, 1967, p 38), para dois outros povos Timbira, os Krikati e Pükob'gateyê' na tentativa de transferi-los para essa Terra. Localiza-se no município de Barra do Corda, as margens do riacho Ourives (COELHO, 1987). Segundo Coelho (1987, p.23) esta área foi “demarcada em 1978 com 2.319 ha”.A tentativa de transferência dos Krikati e Pükob'gateyê' não foi bem sucessida, muitos se recusaram e fugiram. Outros, mesmo concordando com a mudança, retornaram para seu território em pouco tempo (LAVE, 1967, COELHO, 1987). Assim, a Rodeador foi utilizada durante algum tempo pelos Canela e pelos Tentehar como área para plantio e caça (COELHO, 1987) 
da por reconhecimento e revela que essa iniciativa se deu no momento em que trabalhava no escritório da Funai, que administra as ações destinadas aos Tentehar. Trabalhava no setor de limpeza do órgão e começou a ter acesso a documentos, conhecer os direitos indígenas e "como tudo funcionava".

Com o passar do tempo, uma liderança Tentehar, responsável pela Coordenação de Trabalho Local (CTL) da Funai em Barra do Corda, começou a questionar porque os seus parentes eram sempre excluídos das políticas públicas. Obtinha sempre como resposta o fato de que era porque moravam na cidade. Essa foi uma das causas que motivou a sua reivindicação por direitos étnicos e territoriais.

Naquele momento, A. Timbira e seus parentes estavam vivendo na cidade, próximos aos "brancos", não tinham lugar para plantar nem lugar para caçar, a única opção de subsistência era trabalhar na cidade para não indígenas. Vivendo na cidade, ficaram expostos à criminalidade e à discriminação por parte de cidadinos. Começou a reunir os Krenyê de sua família que viviam próximos a ele. Assim, começaram a entrar em contato com os Krenyê que vivem em outras regiões. Passaram, então, a se sentir parte de um grupo maior.

Quando decidiram retornar para a TI Rodeador esta já estava ocupada pelos Tentehar e apesar de receberem apoio de uns para construírem uma aldeia lá, outros se opunham. Para resolverem esse impasse decidiram pedir autorização da Funai em Brasília.

Em 2004, fizeram uma viagem até Brasília. Um grupo composto por 22 Krenyê ficou acampado até serem recebidos por dirigentes da Funai. Dentre as reivindicações, além do atendimento por parte da coordenação local da Funai, em Barra do Corda, estava o pedido de regularização de uma terra para usufruto exclusivo dos Krenyê:

Quando fomos morar na Rodeador, moravam Guajajaras [Tentehar] lá. Os índios de lá, a princípio, não aceitaram, mas, depois de documentos do MPF e da Funai, eles permitiram. Um dos que não aceitaram era J. V. B. Tudo os que os Krenyê precisavam a respeito de saúde e educação tinha que passar pelos Guajajaras. (A. Timbira, primeiro líder do movimento político e atual cacique da aldeia Pedra Branca - TIRodeador ${ }^{31}$ )

Para conseguir essa autorização, segundo a liderança, ficaram acampados no escritório da Funai em Brasília por um mês até conseguirem falar com o representante do órgão. Revelou que nesse momento sua identidade foi colocada em xeque e esse teria sido o estopim que o levou perceber a importância de começarem a se autoafırmar Krenyê.

Naquela época, os Krenyês se autodenominavam genericamente como Timbira. Nas palavras dele, "Timbira pode ser qualquer povo", "pode ser os Krepumkateyê" e eles não poderiam ser confundidos com os Krepumkateyê ou qualquer outro grupo Timbira, por isso precisavam afirmar-se Krenyê.

Assim, além do pedido de proteção, também passaram a demandar reconhecimento da etnia Krenyê: este foi tanto um processo para fora, em que se apresentaram ao Estado, a outros grupos indígenas e à sociedade nacional como Krenyê, quanto um processo para dentro de autocompreensão (BRUBAKER; COOPER, 2000), se acomodando a novas formas de identificação que os constrói como Krenyê. 
Desse modo, iniciaram um processo de resgate da sua história e memória. A memória dos dois mais velhos do grupo, tornouse essencial, transformando-os em figuras importantes desse processo, pois foram os únicos que viveram no território tradicional e experienciaram o início do processo de espoliação do grupo.

Nesse processo de produção do "ser Krenyê”, passaram a levar em consideração as visões externas construídas sobre índios. Visões muitas vezes romantizadas que os constroem a partir de elementos culturais, vestuários, cantos, língua, habitat. Essas visões são construídas pela sociedade civil, mas também fazem parte dos protocolos a serem preenchidos pelos grupos indígenas que estão em processo de reconhecimento pelo Estado.

Como estratégia de ação, começaram a participar de eventos ligados à causa indígena, como reuniões oficiais de orgãos do Estado e índios de outras etnias, assembleias e mobilizações promovidas pelo Conselho Indigenista Missionário (CIMI); também realizaram ocupações em sedes de órgãos públicos como FUNAI e FUNASA (Fundação Nacional de Saúde).

Conseguiram autorização para habitar a TI Rodeador e, em 2009, organizaram uma assembleia denominada: "I Encontro dos povo Krenyê”, que teve como objetivo discutir o andamendo das suas demandas e formalizar o pedido de demarcação de uma Terra Indígena.

Convidaram para essa reunião agentes de alguns orgãos do Estado como aqueles ligados à causa indigena, ligados à educação, saúde, representantes de associações indígenas, outros povos indígenas com os quais mantêm relação, como por exemplo os Tentehar, Gavião, Krepumkateyê, Krikati e os Krenyê que vivem fora da região de Barra do Corda.

0 encontro foi uma forma de apresentá-los como novos atores que, a partir dalí, iam fazer parte do campo indigenísta da região. Uma forma de marcar espaço e inserir-se como atores do "campo político" (SWARTZ, 1968). Os Krenyê agora passariam a disputar com outros índios recursos do Estado, bem como serviriam de parceiro de luta para determinadas reivindicações que pudessem fazer juntos por interesses em comum.

Meses após o encontro, os Krenyê viveram uma situação dramática ${ }^{32}$ (TURNER, 2008) que mudou novamente a rotina. 0 conflito teve como resultado o assassinato de um membro do grupo. Tal episódio teve o envolvimento direto do líder da época. Aqueles que estavam diretamente envolvidos no episódio fugiram levando consigo suas famílias. A fuga de parcela dos Krenyê deixou a aldeia quase vazia, Após o conflito, os Guajajara destruíram a
aldeia. Ficou eu, meu irmão, a filha casada, o
marido e os filhos pequenos. Os outros foram
embora. À noite, os Guajajara invadiram as
aldeias, foram pegando as nossas coisas, ga-
linhas, roupas, mantimentos, fardos de arroz,
panelas, portas, mesas, forno, prensa, tirando
energia de dentro de casa, tocaram fogo nas
casas. A minha filha disse que os Guajajara
anunciaram a chegada de duas carradas de
indios, que iriam matá-los se eles continuas-
sem lá. De lá, fomos para uma vila próxima à
aldeia. De lá, fui para a casa de uma filha que
mora de aluguel em Barra do Corda. Nunca 
mais voltamos lá. Mas antes disso, os Guajajarajá ameaçavam. Saímos da aldeia sem nada, só com a roupa do corpo. (M. Krenyê, idosa moradora da aldeia São Francisco ${ }^{33}$ )

Os Tentehar aproveitaram tal situação e invadiram a aldeia, queimaram as casas e expulsaram os Krenyê da TI Rodeador.

Eu, a mãe e o meu marido não dormimo de noite, no dia do conflito porque os Guajajaras invadiram a aldeia. Meu filho de 14 anos ficou traumatizado, lembrando-se das casas pegando fogo, das galinhas e cachorros gritando. Nós ouvimos os Guajajaras falarem "vai já chegar uma carrada lá do Mussum (aldeia)”. Fomos embora para Barra com medo de sermos mortos pelos Guajajaras. Depois de três dias, quisemos voltar, mas o D. P. disse que os Guajajaras estavam armados na aldeia. Depois de oito dias, voltamos lá e estava tudo destruído. Seu F. ficou chorando ao ver tudo destruído. Os índios não querem voltar para a Rodeador. Não dá certo viver com os Guajajaras. Não é bom ficar junto com os Guajajaras na saúde. (V. Krenyê, filha de M. Krenyê moradora da periferia da cidade de Barra do Corda $^{34}$ )

Os relatos acima demonstram o quanto foi dramática e violenta a segunda saída dos Krenyê da TI Rodeador. A morte de um Krenyê abalou as relações internas, somaram-se a isso uma série de acusações de roubo e desvio de recursos dirigidas ao líder. Esses fatos levaram, em 2009, à divisão do povo e desinstituição da liderança do movimento na época.
Quando desinstituíram o líder, alguns saíram em busca de um substituto, o filho de M. Krenyê, para que pudesse ficar à frente de todo processo de luta por direitos sociais e territoriais. Naquele momento, o filho de M. Krenyê vivia na TI Geralda Toco Preto dos Krepumkatyê, era vice cacique da aldeia e sua esposa, que é Krepumkateyê, cacique. A pedido da comunidade, aceitou o posto e retornou para junto dos Krenyê.

0 novo líder, R. Krenyê, filho de M. Krenyê, é visto por uma parcela dos Krenyê que moram em Barra do Corda, mais precisamente os que habitam a aldeia São Francisco, como inteligente e digno de ocupar essa posição, pois sabe lidar com os órgãos do Estado e brigar pela causa indígena. Este líder é considerado "honesto" e "bondoso" na medida em que, segundo eles, sabe dividir os recursos com a comunidade, oportuniza a participação de todos em eventos fora da aldeia e explica todas as suas ações.

Após o conflito e divisão interna, os Krenyê que estão em Barra do Corda passaram habitar áreas diferentes. 0 antigo líder do movimento retornou, junto com sua família, para a TI Rodeador e construiu lá sua aldeia. A aldeia é formada por seus filhos e os parentes da sua mulher. A parcela ligada ao atual líder conseguiu comprar o sítio "aldeia São Francisco”, com o dinheiro da aposentadoria de um dos idosos, na zona rural da cidade, e passaram a viver lá, compondo um conjunto de seis famílias, incluindo os dois idosos F. Krenyê e M. Krenyê. E na periferia da cidade moram mais três famílias, que mantêm relações tanto com os que mo-

32. Segundo Turner (2008), os "dramas sociais" acontecem em momentos em que interesses e atitudes de grupos de individuos estão em oposição. Afırma, o autor, que os "dramas sociais" são unidades do processo que surgem em situações de conflito.

33. Depoimento concedido ao Ministério Público Federal-MA, 2010.

34. Depoimento concedido ao Ministério Público Federal-MA, 2010. 
ram na Terra Rodeador quanto com os que moram na aldeia São Francisco, alternando o apoio entre os dois grupos.

Além da divisão entre os próprios Krenyê, ainda tem ocorrido uma série de acusações trocadas entre os diferentes grupos. 0 atual grupo líder do movimento acusa o antigo líder de não ser Krenyê, pois seu pai é índio Tentehar e sua mãe seria branca. Junto a essa questão do sangue hereditário, vem também a acusação de que o antigo líder não sabe a língua, não sabe os cantos, e nem sabe como realizar as festas. Não sabe os mitos.

Enquanto isso, o antigo líder defende-se dizendo que se não fosse a mistura os Krenyê não existiriam mais, pois os casamentos interétnicos foram a única opção quando se viram em um grupo reduzido de pessoas sem a possibilidade de parceiros para trocas matrimoniais. Ao mesmo tempo em que se defende, acusa o outro líder de ter vivido junto aos Krepunkatayê, enquanto ele estava ao lado dos Krenyê e deu início a todo processo de demanda identitária e por direitos. Acusam, ainda, o atual líder de não saber nada a respeito do início de todo processo de luta política.

No entanto, defendem esse novo líder como sendo um bom líder, por ter boas relações com funcionários locais dos órgãos do Estado, com os outros índios da região, com pessoas importantes da região. Segundo ele, se estivesse à frente do movimento de demanda por território já teriam conseguido uma terra. E acusa a esposa do líder atual, que é Krepumkateyê, e o CIMI, de serem culpados pela briga e divisão do grupo.

Assim, se por um lado parece que as relações estabelecidas constroem, no momento, Krenyê como aqueles que estabelecem um sistema de parceria e colaboração com todos do pequeno grupo à frente do movimento, por outro lado, julgam ser de fora aquele que se afastou demais e não contribui para o bem estar do grupo.

Quando o antigo líder saiu da liderança fez uso da frase, "agora eu vou cuidar só do meu povo, que é a minha família, vocês cuidam de vocês" ${ }^{35}$. Essa frase é sempre repetida quando afırmam que o antigo líder não é um Krenyê.

Em uma conversa com a idosa $\mathrm{M}$. Krenyê, afırma: "Ele disse que vai cuidar só do povo dele, mas o povo dele são tudo branco, só tem branco naquela aldeia [aldeia Pedra Branca], são os parentes da mulher dele. E ele é Guajajara. Só tem dois Krenyê naquela aldeia, são os netos da V. Krenyê". M. Krenyê refere-se aos seus bisnetos, que nasceram do casamento do filho de V. Krenyê com a filha de A. Timbira.

0 fato do antigo líder ter deixado de ajudá-los parece ser o motivo pelo qual passaram a considerá-lo como não Krenyê, porém usam a questão do sangue e dos conhecimentos sobre a cultura ou a língua como justificativa para sustentar seus argumentos.

Vemos que dentro desse processo de subjetivação, tanto singular quanto coletiva (BHABHA, 2005), que dão início a novos signos de identidade, os Krenyê tanto investem na produção de uma identidade Krenyê quanto gestam as relações de poder.

A produção da identidade Krenyê versa sobre quem tem sangue Krenyê, ou quem sabe cantar, falar a língua, sabe os mitos etc. Esses traços podem ser moldados e negociados.

\section{Considerações finais}

Buscamos apresentar brevemente os diversos elementos constitutivos do processo de reorganização social Krenyê. Para tanto, procuramos refazer o percurso histórico percorrido pelos Krenyê desde o início do pro- 
cesso de expropriação territorial. A espoliação territorial dos Krenyê tem relação direta com o processo e colonização que os levou a diferentes processos de "territorialização".

0 processo de luta por reconhecimento, que tem início nos primeiros anos do século XXI, é alimentado pela crença de se constituírem um povo, portanto, capazes de acessar direitos específicos. A memória dos mais velhos e os conhecimentos repassados por eles ajudam a dar suporte à crença em uma "cultura Krenyê" que foi solapada por forças coloniais, mas que pode agora ser "resgatada”. É também por meio dos mais idosos que a língua, os mitos e a história pode ser "resgatada". A memória é trabalhada objetivando dar sentido a experiência coletiva, justificando práticas no presente e construindo planos para o futuro.

Assim, o "ser Krenyê" vem sendo construído ao longo desse processo e é influenciado tanto pelo passado quanto pelo presente, tanto por experiências apreendidas através da vivência com outros povos indígenas quanto por ensinamentos apreendidos através da alianças construídas com não indígenas, a exemplo do Conselho Indigenista Missionário, de pesquisadores, agentes do Ministério Público, funcionários dos órgãos indigenistas, e outros.

Uma situação social vivida após o "I Encontro do Povo Krenyê”, abala as relações internas, provoca rupturas, e instaura crises, conflitos e disputas identitárias e territoriais configurando um "drama social” (TURNER, 2008). Este drama leva-os novamente à vida na cidade dificultando não só a vida cotidiana, mas também o acesso a determinados direitos, como saúde e educação.
Os Krenyê ainda estão passando por processos de territorialização, estão submetidos a políticas indigenistas, porém ainda não conseguiram a posse de um território próprio. Assim, apesar do Estado, através de sua agência indigenista, conseguir influenciar algumas estratégias e ações traçadas e desempenhadas pelos Krenyê, tem a sua administração dificultada pelo fato dos Krenyê encontrarem-se dispersos e fora de uma unidade jurídico-política própria.

\section{Referências}

ARRUTI, J. M. A emergência dos "remanescentes": notas para o diálogo entre indigenas e quilombolas. Mana, v.3,n 2, p.7-38,1997.

. Etnogêneses Indigena. Povos Indígenas no Brasil. São Paulo: Instituto Socioambiental. 2006.

BARTH, F. Os grupos étnicos e seus limites. In: POUTGNAT, P. ; STREIFF-FENART, J. Teorias da etnicidade. São Paulo: UNESP, 1998. p. 185-227.

O Guru, o Iniciador e Outras Variações Antropológicas Organização de TomkeLask. Rio de Janeiro: Contra Capa Livraria, 2000.

BARTOLOMÉ, M. A. As Etnogêneses: velhos atores e novos papéis no cenário cultural e político. Mana, Rio de Janeiro, v. 12, n. 1, p.39-68, 2006.

BENJAMIN, W. Walter Benjamin: Obras Escolhidas Volume I: Magia e Técnica, Arte e Política. São Paulo: Editora Brasiliense, 1987.

BHABHA, H. K. 0 local da cultura. Trad. Myriam Ávila, Eliana Lourenço de Lima Reis e Gláucia Renate Gonçalves. Belo Horizonte: Editora da UFMG, 2005.

BRASIL/ FUNAI. Ministério da Justiça. Fundação Nacional do Índio. Relatório circunstanciado de constituição da reserva indigena Krenyê. ALMEI-

35. Frase proferida em uma reunião dos Krenyê em Barra do Corda juntamente com o CIMI e a Pastoral indigenista em 2009. 
DA, Emerson Rubens Mesquita de (coord). Brasília, 2015.

BRUBAKER, R.; COOPER, F. Beyond "identity". Theory and society 29, p. 1-47, 2000.

CARDOSO DE OLIVEIRA, R. Caminhos da identidade: ensaios sobre etnicidade e multiculturalismo. São Paulo: Ed. da UNESP; Brasília: Paralelo, 2006.

COELHO, E. M. B. A política indigenista no Maranhão provincial. São Luís, SIOGE, 1991.

Cultura e sobrevivência dos índios no Maranhão. São Luís, EDUFMA, 1987.

DACOSTA, L. P. (Org.). Bacabal - MA. In:

Atlas do Esporte no Brasil. Rio de Janeiro: CONFEF, 2006. p. 44- 50.

DELORIA JUNIOR, V. God is Red: A native view of religion. Golden, CO: Fulcrum Publishing, 1994.

GALLOIS, D. T. Gêneses waiãpi, entre diversos e diferentes. Revista de Antropologia, v. 50, n. 1, p. 45-83, 2007.

Terras? Territórios? Territorialidades? In: RICARDO, F. (Org.). Terras Indigenas \& Unidades de Conservação da natureza: o desafio das sobreposições. São Paulo: Instituto Socioambiental, 2004, p. 37-41.

GODOI, E. P. Territorialidade: trajetória e usos do conceito. Raizes, v.34, n.2, p. 8-16, jul-dez /2014.

GOMES, M. P. 0 índio na história: 0 povo Tenetehara em busca da liberdade, Petrópolis: Vozes, 2002.

HAESBAERT, R. Desterritorialização e identidade: a rede "gaucha" no Nordeste. Niterói: EDUFF, 1997.

HONNETH, A. Luta por reconhecimento: a gramática moral dos conflitos sociais. São Paulo: Ed.34, 2003.

LAVE, J. C. Social Taxonomy among the Krikati(Jê) of central Brazil. Harvard University, December, 1967.

LITTLE, P. E. Territórios Sociais e Povos Tradicionais no Brasil: Por uma antropologia da territorialidade. In: Série Antropologia, Brasília, 2002.
Disponivel em: <http://nute.ufsc.br/bibliotecas/ upload/paullittle.pdf> Acesso em: 14 jun. 2015.

MACHADO, E. O.Apontamentos, "Colonisação." Sotero dos Reis. Rev. Inst. Hist., v. 19. Rio de Janeiro, 1856.

NIMUENDAJU', K. The Eastern Timbira.University of California Press, 1946.

OLIVEIRA, J. P. 0 nosso governo: os Ticuna e o regime tutelar. São Paulo: Marco Zero; Brasília: MCT/CNPq, 1988.

. A difícil etnografia de uma tribo em mudança. Disponível em <http://www.dan.unb.br/ anuario-antropologico-listagem-dos-numeros/140 anuárioantropologico-sumario-1981>. Acesso em: 20 jun. 2017.

. Uma etnologia dos índios misturados? Situação colonial, territorialização e fluxos culturais. In: __ (Org.). A viagem da volta: etnicidade, política e reelaboração cultural no Nordeste indígena. Rio de Janeiro: Contra Capa, 1999. p. 11-39.

(Org.). lndigenismo e territorialização:poderes rotinas e saberes coloniais no Brasil contemporâneo. Rio de Janeiro: Contra Capa Livraria 1998.

Regime tutelar e faccionalismo: política e religião em uma reserva Ticuna. Manaus: UEA edições, 2015.

OLIVEIRA, João Pacheco de; FREIRE, Carlos Augusto da Rocha. A Presença Indigena na Formação do Brasil. Brasília: MEC, LACED/Museu Nacional, 2006.

RIBEIRO, D. Os índios e a civilização: a integração das populações indígenas no Brasil Moderno. São Paulo: Companhia das Letras, 1996.

RIBEIR0, F. P. Memória sobre as nações gentias que presentemente habitam o continente do Maranhão. Revista Trimensal de História e Geographia. Rio de Janeiro, 1841. p.184-197.

Memórias dos sertões maranhenses. São Luis: Seciliano, 1982. 
RODRIGUES, A. D. Línguas brasileiras: para o conhecimento das línguas indígenas. São Paulo: Loyola, 1986.

SACK, R. D. Conceptions of space in social thought: a geographic perspective. Minneapolis: University of Minnesota Press, 1980.

SWARTZ, M. Introduction. In: M. (Org.). Local-Level Politics. Chicago, Illinos: Aldine Plublishing Company, 1968. p. 1-46.

TURNER, V. W. Dramas campos e metáforas: ação simbólica na sociedade humana. Niterói: EDUFF, 2008.

VELHO, O. G. Frentes de expansão e estrutura agrária: estudo do processo de penetração numa área da Transamazônica. 3. ed. Manaus: UEA Edições, 2013.

WEBER, M. Relações comunitárias étnicas. In: .Economia e sociedade: fundamentos da sociologia compreensiva. v. 1. Brasília: UnB, 2000. p. 267-277. 
RESUMO

0 presente trabalho visa apresentar a trajetória dos Krenyê, um povo indígena historicamente deslocado de seu território. Esta situação provocou uma série de processos diferenciados de territorializações e novos deslocamentos, que todavia não foram capazes de dirimir o sentido de território impresso nos modos de criar, fazer e viver dos Krenyê. 0 objetivo deste trabalho é analisar esses diferentes processos, que marcam a história desse povo indígena, identificando de que modo eles vão construindo tecituras nos diferentes trajetos percorridos. Assim, pretendemos ressaltar o caráter histórico e transitório das identidades e as questões políticas e estratégicas colocadas pela necessidade de assegurar o reconhecimento e a conquista de demandas políticas e territoriais.

\section{PALAVRAS-CHAVE}

Território. Etnicidade. Reconhecimento. Territorialização.

\section{ABSTRACT}

In this article, I explore the trajectory of the Krenyê, indigenous people historically displaced from their territory. This situation resulted series of differentiated processes of territorialisations and new displacements that, however, were not able to solve the sense of territory printed in Krenye's ways of creating, doing and living. The objective of this paper is to analyze these different processes, which mark the history of this indigenous people, identifying how they build weaving in the different paths covered. Thus, we intend to emphasize the historical and transitory character of identities and the political and ethnographic issues raised by the Krenyê's need to achieve recognition of identity and territory where these may be in conflict with one another.

\section{KEYWORDS}

Territory.Ethnicity.Recognitions.Territorialisation. 
